\title{
Prediction of the performance of synthetic sheep strains utilizing Finnsheep and native sheep breeds in Egypt
}

\author{
H. MANSOUR ${ }^{1}$ and A. M. ABOUL-NAGA ${ }^{2}$
}

${ }^{I}$ Department of Animal Production, Faculty of Agriculture, Ains Shams University, Shubra Al-Khaima, Cairo, Egypt

${ }^{2}$ Animal Research Institute, Ministry of Agriculture, Dokki, Cairo, Egypt

\begin{abstract}
This investigation was carried out to estimate individual and maternal heterotic components for ewe productivity traits to enable predicting the performance of synthetics including local (Rahmani (R) and Ossimi (O)) and Finn (F) inheritance.

Reproduction performance traits studied were number of ewes conceived (ECJ), number of lambs born (LBJ), number of lambs at four months of age (L4J), kilograms born (KBJ) and kilograms at four months of age (K4J), all being per ewe joined, and number of lambs born (LBL), number of lambs at four months of age (L4L), kilograms born (KBL) and kilograms at four months of age (K4L), all being per ewe lambed.

Results indicate an expected increase of $0.32,0.19,0.50$ and 0.27 in LBJ, L4J, LBL and L $4 \mathrm{~L}$ for F.R and $0.32,0.23,0.59$ and 0.40 in the same traits for. F.O after two generations of inter se mating, respectively. For FR.R and FO.O the improvements were $(0.18,0.18),(0.13$, $0.15),(0.22,0.28)$ and $(0.15,0.22)$ in $\mathrm{LBJ}, \mathrm{L} 4 \mathrm{~J}, \mathrm{LBL}$ and $\mathrm{L} 4 \mathrm{~L}$, resp.

It can be concluded that introducing the $\mathrm{F}$ to the local subtropical sheep in Egypt would substantially improve their reproductive performance whether for implementation at the small farmer level (quarter F) or at higher intensification level (half F).
\end{abstract}

Index words: Finnsheep, Rahmani, Ossimi, crossbreeding, heterosis, synthetics, fertility, prolificacy, ewe productivity

\section{Introduction}

In 1974, the Egyptian Ministry of Agriculture (MOA) started a crossbreeding program to improve the productivity of two native sheep breeds through crossing with the prolific Finnsheep $(\mathrm{F})$. The program aimed at the development of improved synthetic lines of sheep with higher reproduction rate than the local sheep and suited to the prevailing subtropical conditions.

This investigation was carried out to estimate individual and maternal heterotic components for ewe productivity traits to enable the estimation of performance of synthetics 
including different portions of local and $\mathrm{F}$ inheritance.

\section{Materials and methods}

Data were collected from two MOA experimental farms and consisted of 5520 records from 1316 ewes during 1974-1986. Flocks were raised under an accelerated lambing system of three crops every two years (each two years were considered a block). Mating seasons lasted for 35 days and were in September, May and January, and lambs were weaned at eight weeks of age.

The plan was to mate F rams to both Rahmani $(\mathrm{R})$ and Ossimi $(\mathrm{O})$ ewes to produce halfbreds (FR \& FO), respectively which were used to produce both reciprocal back crosses ((F.FR \& FR.R) and (O.FO \& RO.O), respectively, that were inter se mated.

Nine different measurements of reproduction performance were evaluated. Those related to fertility were: number of ewes conceived (ECJ), number of lambs born (LBJ), number of lambs at four months of age (L4J), kilograms born (KBJ) and kilograms at four months of age (K4J), all being per ewe joined. Those related to prolificacy were: number of lambs born (LBL), number of lambs at four months of age (L4L), kilograms born (KBL) and kilograms at four months of age (K4L), all being per ewe lambed.

Data were analyzed by a least-squares fixed model, including effect of flock, block, season of mating, parity and interactions between flock and block, season and parity and block and season along with four covariate terms. The covariate terms accounted for: (1) difference between each of $\mathrm{R}$ or $\mathrm{O}$ minus $\mathrm{F}$ for direct effect of individual genes (gi), (2) difference between each of $\mathrm{R}$ or $\mathrm{O}$ minus $\mathrm{F}$ for maternal environment of genes of the individual's dam, (gm) (3) individual heterosis between R \& F and O \& F, (hi) and (4) maternal heterosis between R \& F and O \& F (hm). Coefficients of these covariate terms for different types of matings were, according to Dickerson (4), as follows ( $\mathrm{L}=$ local):

$\begin{array}{lcccc} & g i & g m & h i & h m \\ \text { FF } & -1 & -1 & 0 & 0 \\ \text { LL } & 1 & 1 & 0 & 0 \\ \text { FL } & 0 & 1 & 1 & 0 \\ \text { L.FL } & 1 / 2 & 0 & 1 / 2 & 1 \\ \text { FL.L } & 1 / 2 & 1 & 1 / 2 & 0 \\ \text { (FL.L)2 } & 1 / 2 & 1 / 2 & 3 / 8 & 1 / 2\end{array}$

Both breed paternal effect and paternal heterosis were assumed negligible.

\section{Results and discussion}

Dickerson $(4,5)$ discussed methods for utilizing the genetic diversity among breeds and factors determining it such as (1) individual (IG), maternal (IM) and paternal (IP) performance of purebreds and recombinations (R) effects in gametes produced by crossbred parents and (2) heterosis for individual (hi), maternal (hm) and paternal performance (hp). IG, IM and IP performances of a specific breed are non-estimable. In contrast differences between breeds in individual (gi), maternal (gm) and paternal (gp) are estimable. Heterosis for individual, maternal and paternal between breeds are estimable if the models and breed combinations used for the estimation are appropriate.

This study aims at estimating the differences between local (L) -F purebreds individual breed and maternal effects and both individual and maternal heterosis.

Estimates of gi, gm, hi and hm and their standard errors, from R-F and O-F analyses, are presented in table 1 . These estimates were utilized in predicting potential difference between native sheep and pure $F$ and different $\mathrm{L} \times \mathrm{F}$ crossbreds (table 2 ), calculations were made according to the genetic expectations of both pure- and cross-breds, as in A-N and G (1).

The relatively large standard errors, associated with the estimates in table 1 , are mainly a result of the large estimates of the error mean square of the traits studied. The total coefficient of determination (R2) from fitting the proposed model in this study for ewe reproduction traits were too low, $(0.09-$ 
Table 1. Least squares estimates of gi, gm, hi and hm (multiplied by 100) from Finn-Rahmani and Finn-Ossimi crossbreds (and standard errors).

\begin{tabular}{|c|c|c|c|c|c|c|c|c|}
\hline & \multicolumn{4}{|c|}{ Finn-Rahmani } & \multicolumn{4}{|c|}{ Finn-Ossimi } \\
\hline & gi & $\mathrm{gm}$ & hi & $\mathrm{hm}$ & gi & $\mathrm{gm}$ & hi & $\mathrm{hm}$ \\
\hline \multicolumn{9}{|l|}{ Fertility } \\
\hline ECJ & $\begin{array}{c}34 \\
(17)\end{array}$ & $\begin{array}{c}-27 \\
(17)\end{array}$ & $\begin{array}{c}40 \\
(17)\end{array}$ & $\begin{array}{r}-27 \\
(16)\end{array}$ & $\begin{array}{r}-80 \\
(54)\end{array}$ & $\begin{array}{c}91 \\
(53)\end{array}$ & $\begin{array}{r}-76 \\
(54)\end{array}$ & $\begin{array}{c}83 \\
(53)\end{array}$ \\
\hline LBJ & $\begin{array}{l}27 \\
(28)\end{array}$ & $\begin{array}{r}-49 \\
(28)\end{array}$ & $\begin{array}{c}66 \\
(28)\end{array}$ & $\begin{array}{c}-49 \\
(27)\end{array}$ & $\begin{array}{r}-199 \\
(86)\end{array}$ & $\begin{array}{l}175 \\
(85)\end{array}$ & $\begin{array}{r}-159 \\
(86)\end{array}$ & $\begin{array}{l}175 \\
(85)\end{array}$ \\
\hline L4J & $\begin{array}{c}36 \\
(27)\end{array}$ & $\begin{array}{r}-41 \\
(28)\end{array}$ & $\begin{array}{c}69 \\
(27)\end{array}$ & $\begin{array}{r}-41 \\
(26)\end{array}$ & $\begin{array}{r}-145 \\
(81)\end{array}$ & $\begin{array}{l}136 \\
(80)\end{array}$ & $\begin{array}{r}-107 \\
(81)\end{array}$ & $\begin{array}{l}137 \\
(81)\end{array}$ \\
\hline KBJ & $\begin{array}{l}184 \\
(87)\end{array}$ & $\begin{array}{r}-192 \\
(82)\end{array}$ & $\begin{array}{l}258 \\
(86)\end{array}$ & $\begin{array}{r}-190 \\
(84)\end{array}$ & $\begin{array}{r}-559 \\
(277)\end{array}$ & $\begin{array}{c}543 \\
(275)\end{array}$ & $\begin{array}{c}-488 \\
(277)\end{array}$ & $\begin{array}{c}545 \\
(275)\end{array}$ \\
\hline K4J & $\begin{array}{c}396 \\
(397)\end{array}$ & $\begin{array}{r}-345 \\
(304)\end{array}$ & $\begin{array}{c}825 \\
(391)\end{array}$ & $\begin{array}{c}347 \\
(389)\end{array}$ & $\begin{array}{l}-834 \\
(1190)\end{array}$ & $\begin{array}{c}845 \\
(1192)\end{array}$ & $\begin{array}{l}-381 \\
(1192)\end{array}$ & $\begin{array}{r}791 \\
\text { (1181) }\end{array}$ \\
\hline \multicolumn{9}{|c|}{ Prolificacy } \\
\hline LBL & $\begin{array}{l}-9 \\
\text { (22) }\end{array}$ & $\begin{array}{r}-50 \\
(22)\end{array}$ & $\begin{array}{c}32 \\
\text { (22) }\end{array}$ & $\begin{array}{c}-51 \\
(22)\end{array}$ & $\begin{array}{r}-19 \\
(64)\end{array}$ & $\begin{array}{c}55 \\
(63)\end{array}$ & $\begin{array}{r}-77 \\
(64)\end{array}$ & $\begin{array}{r}66 \\
(63)\end{array}$ \\
\hline L4L & $\begin{array}{c}5 \\
(25)\end{array}$ & $\begin{array}{r}-29 \\
(25)\end{array}$ & $\begin{array}{c}38 \\
(24)\end{array}$ & $\begin{array}{c}-31 \\
(24)\end{array}$ & $\begin{array}{r}-77 \\
(72)\end{array}$ & $\begin{array}{c}45 \\
(72)\end{array}$ & $\begin{array}{r}-37 \\
(72)\end{array}$ & $\begin{array}{c}55 \\
(72)\end{array}$ \\
\hline KBL & $\begin{array}{c}70 \\
(61)\end{array}$ & $\begin{array}{r}-137 \\
(61)\end{array}$ & $\begin{array}{l}124 \\
(62)\end{array}$ & $\begin{array}{r}-139 \\
(62)\end{array}$ & $\begin{array}{r}-303 \\
(193)\end{array}$ & $\begin{array}{c}214 \\
(192)\end{array}$ & $\begin{array}{r}-252 \\
(194)\end{array}$ & $\begin{array}{c}255 \\
(192)\end{array}$ \\
\hline $\mathrm{K} 4 \mathrm{~L}$ & $\begin{array}{l}-20 \\
(378)\end{array}$ & $\begin{array}{l}-97 \\
(378)\end{array}$ & $\begin{array}{c}357 \\
(372)\end{array}$ & $\begin{array}{r}-132 \\
(371)\end{array}$ & $\begin{array}{c}683 \\
(1096)\end{array}$ & $\begin{array}{l}-921 \\
(1088)\end{array}$ & $\begin{array}{c}1108 \\
(1098)\end{array}$ & $\begin{array}{l}-858 \\
(1088)\end{array}$ \\
\hline
\end{tabular}

Table 2. The predicted values for the difference between performance of different genotypes minus the local Rahmani and Ossimi.

\begin{tabular}{|c|c|c|c|c|c|c|c|c|c|}
\hline \multirow[t]{2}{*}{ Difference } & \multicolumn{5}{|c|}{ Fertility } & \multicolumn{4}{|c|}{ Prolificacy } \\
\hline & ECJ & LBJ & L4J & KBJ & K4J & LBL & L4L & KBL & K4L \\
\hline Rahmani & * & * & * & & & ${ }^{*}$ & * & & \\
\hline F.F & 14 & -46 & -10 & -0.17 & 1.02 & -118 & -48 & -1.34 & -2.32 \\
\hline F.R & -6 & -40 & -33 & -0.74 & -4.29 & -42 & -33 & -0.54 & -3.76 \\
\hline R.F & -33 & -88 & -74 & -2.67 & -7.74 & -91 & -26 & -1.91 & -4.72 \\
\hline (R.F)2 & 14 & -7 & 1 & 0.52 & -0.15 & -24 & -12 & 0.10 & -1.62 \\
\hline (F.R)3 & 0 & -32 & -19 & -0.43 & -1.88 & -50 & -28 & -0.60 & -2.28 \\
\hline R.FR & -3 & -20 & -16 & -0.40 & -2.13 & -19 & -14 & -0.25 & -1.53 \\
\hline FR.R & -3 & -20 & -16 & -0.37 & -2.14 & -21 & -17 & -0.27 & -1.88 \\
\hline (FR.R)2 & 2 & -12 & -8 & -0.06 & -1.11 & -16 & -11 & -0.11 & -1.26 \\
\hline (FR.R)3 & -1 & -18 & -13 & -0.30 & -1.54 & -23 & -15 & -0.28 & -1.42 \\
\hline \multicolumn{10}{|l|}{ Ossimi } \\
\hline F.F & 23 & -48 & -17 & -0.30 & 0.24 & -129 & -63 & -1.79 & -4.76 \\
\hline F.O & -4 & -41 & -38 & -0.71 & -4.52 & -42 & -40 & -0.51 & -4.26 \\
\hline O.F & 97 & 35 & 99 & 4.72 & 3.93 & 12 & 58 & 1.63 & -13.46 \\
\hline (O.F)2 & -34 & -20 & -92 & -3.17 & -5.88 & -92 & -68 & -2.18 & 0.66 \\
\hline (O.F)3 & 8 & -32 & -23 & -0.44 & -1.93 & -59 & -40 & -0.91 & -3.63 \\
\hline O.FO & 6 & -20 & -19 & -0.37 & -1.72 & -32 & -29 & -0.66 & -2.76 \\
\hline FO.O & -2 & -20 & -19 & -0.36 & -2.26 & -21 & -20 & -0.26 & -2.13 \\
\hline (FO.O)2 & -7 & -40 & -32 & -0.97 & -2.47 & -36 & -29 & -0.78 & -1.06 \\
\hline (FO.O)3 & 3 & -18 & -15 & -0.29 & -1.48 & -28 & -22 & -0.46 & -2.13 \\
\hline
\end{tabular}

* Estimates are multiplied by 100 .

$0.18)$ and $(0.18-0.30)$ for fertility and prolificacy traits, respectively. This is in agreement with R2 estimates reported in the litera- ture (3). Also, the contribution of the genetic part to the intra-breed total variation for these traits are low (6). This would lead to a rela- 
tively large contribution of the unexplained variation.

Egyptian native breeds, though are well adapted to the environment and the ewe is fertile all year round (2), greatly lack on litter size, a useful trait in any intensification system. MOA plan was to produce a ewe with low $\mathrm{F}$ inheritance, hence the $1 / 4 \mathrm{~F} 3 / 4 \mathrm{~L}$, where the small holder can afford the inputs required. However, with some intensive lamb production systems, now in operation in Egypt with more than 15000 ewes, there seems a room for larger degree of intensification utilizing ewes of higher inheritance of prolific breeds i.e. 1/2 F 1/2 L.

Results in table 2 indicate an expected im-

\section{References}

1. Aboul-Naga, A.M. \& E.S.E. Galal (1973). A note on the effect of interbreeding among backcrosses of sheep breeds. Anim. Prod. 16 (1): 87-90.

2. Aboul-Naga, A.M., M.B. Aboul-Ela, H. Mansour \& M. GABR (1988). Reproductive Performance of crosses between Finn and non-seasonal Egyptian sheep breeds under accelerated lambing system. Small Ruminant Res. (Submitted).

3. Ацманdy, H. (1987). Estimation of genetic parameters of some reproductive traits in native fattailed sheep. M. Sc. thesis, University of Assiut, Assiut Egypt. provement of $(0.32,0.19),(0.32,0.23),(0.18$, $0.13)$ and $((0.18,0.15)$ in LBJ and L4J for F.R, F.O, R.RF and O.OF after two generation of inter se mating, respectively. The expected increase in $\mathrm{LBL}$ and $\mathrm{L} 4 \mathrm{~L}$ are $(0.50$, $0.28),(0.59,0.40),(0.23,0.15)$ and $(0.28$, 0.22 ) for the same synthetics, respectively.

It can be concluded that introducing the $\mathrm{F}$ to the local Egyptian breeds would substantially improve their lamb output at different levels of $\mathrm{F}$ inheritance. However, the costs of these schemes in relation to their potential economic benefits and the performance of these crosses under the breeders condition should be evaluated before any wide scale application.

4. Dickerson, G.E. 1969. Experimental approaches in utilizing breed resources. Anim. Breed. Abstr. 37: 191.

5. DiCKerson, G.E: 1973. Inbreeding and heterosis in animals. In: Proc. of Animal Breeding and Genetics Symp. in Honor of Dr. Jay L. Lush. pp. 54-77. Amer. Soc. Anim. Sci., Champaign, IL.

6. Hanrahan, J.P. \& J.F. Quirke (1985). Contribution of variation in ovulation rate and embryo survival to within breed variation in litter size. In Genetics of Reproduction in Sheep. (Eds. Land, R. and Robinson, D.): 193-201. 